SZÉKFOGLALÓ ELŐADÁSOK A MAGYAR TUDOMÁNYOS AKADÉMIÁN

\author{
Jean Salençon
}

\title{
ON THE VIRTUAL WORK APPROACH TO THE MODELLING OF FORCES
}


Jehintetes Aagy yy

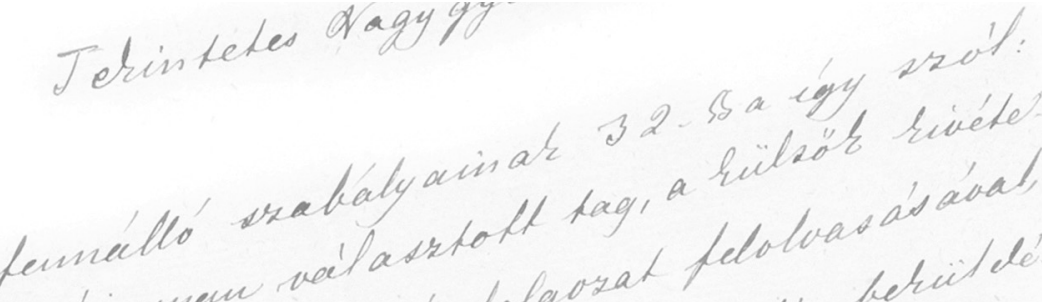
- rijonnan veil astott tag, a hillso"s hivété stályaba tartoso' dolgosat felotwar ás ával,

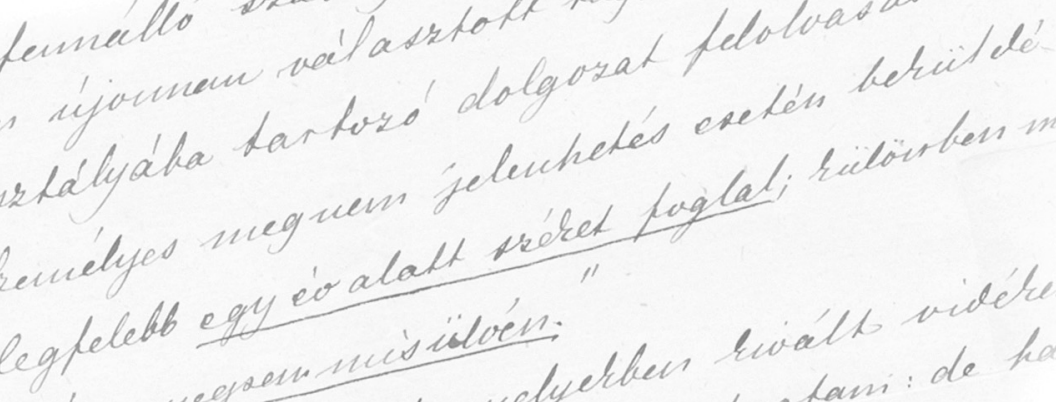

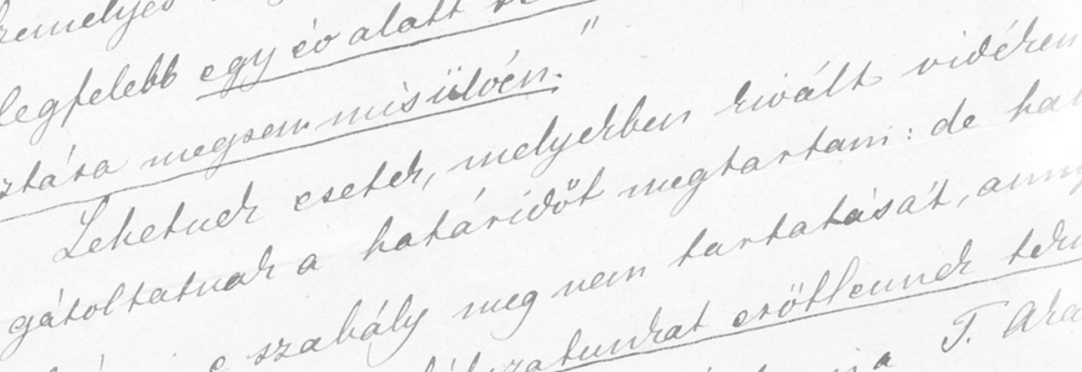
chésui e szabály sueg nem tartataisats, am

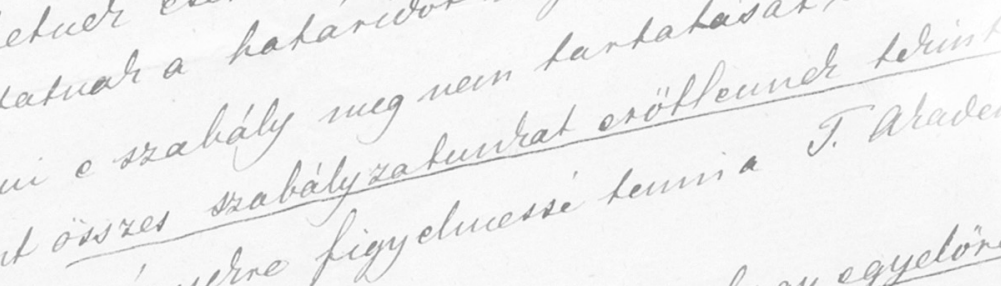

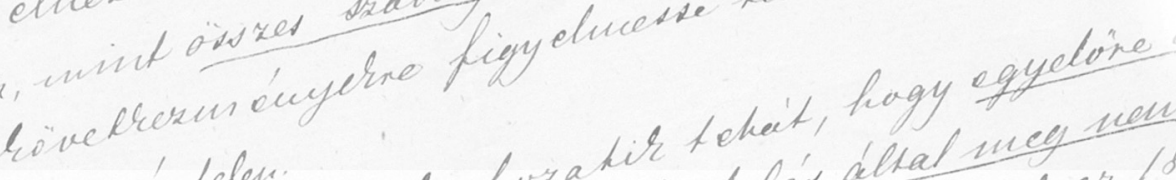
srierségtelen.

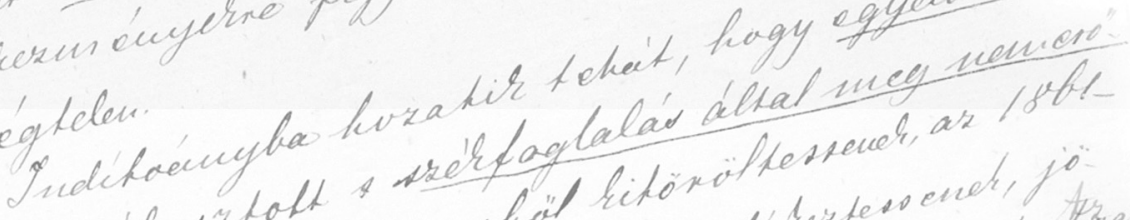

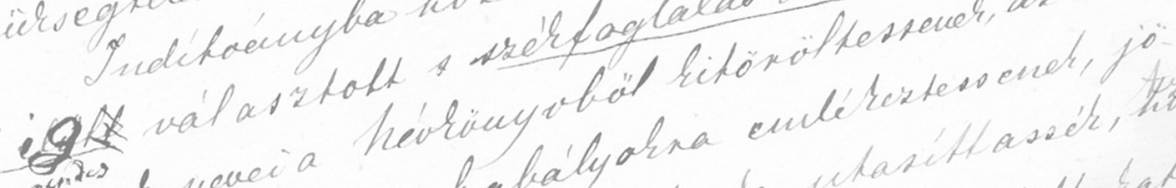

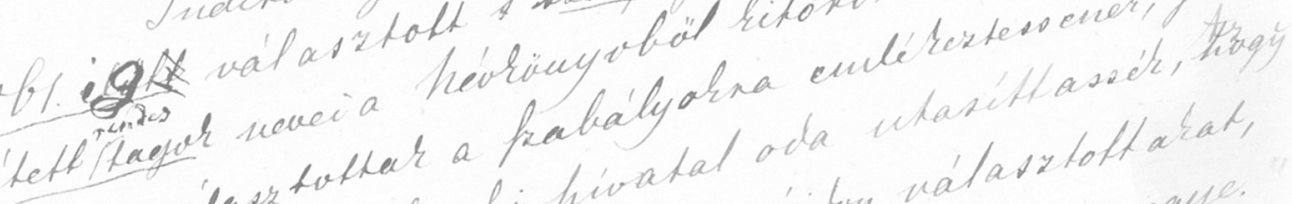

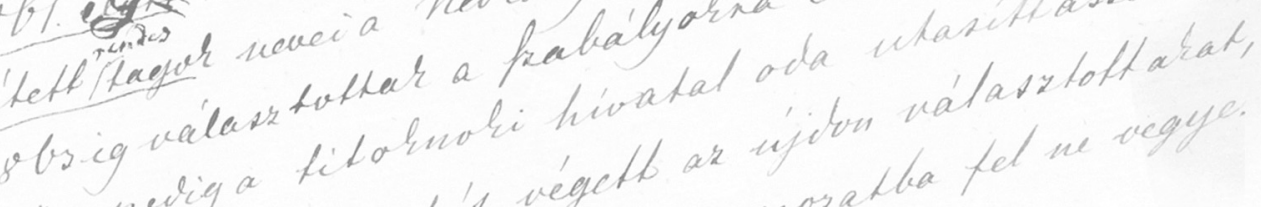

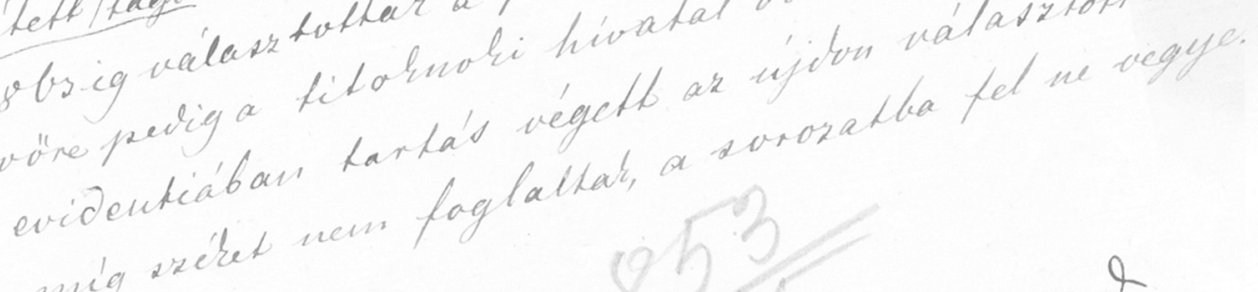
mig weket nem fogtathatio

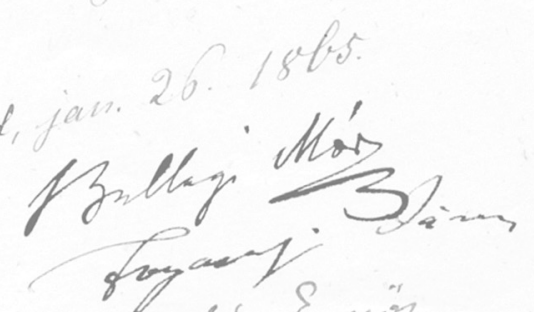

13 Kenciong Liagriont conituria Lastoz

Alás Eviös

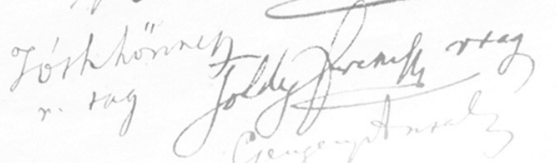


Jean Salençon

ON THE VIRTUAL WORK APPROACH TO THE MODELLING OF FORCES 


\title{
SZÉKFOGLALÓK \\ A MAGYAR TUDOMÁNYOS AKADÉMIÁN
}

\section{INAUGURAL LECTURES AT THE HUNGARIAN ACADEMY OF SCIENCES}

\author{
A 2013. május 6-án megválasztott \\ akadémikusok székfoglalói
}

Inaugural lectures by new members

elected on 6 May, 2013 


\section{Jean Salençon}

\section{ON THE VIRTUAL WORK}

APPROACH TO THE

MODELLING OF FORCES

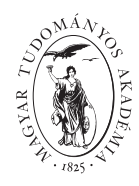

Magyar Tudományos Akadémia • 20I4 


\title{
Az elōadás elhangzott 20I4. május I2-én Delivered on I2 May, 2014
}

\author{
Sorozatszerkesztô• Series editor: Bertók, Krisztina
}

Angol nyelvi lektor • English reader: Torkos, Béla

Borító és tipográfia $\bullet$ Cover and typography: Auri Grafika

ISSN $1419-8959$

ISBN 978-963-508-797-6

(C) Jean Salençon

Kiadja a Magyar Tudományos Akadémia • Published by the Hungarian Academy of Sciences Kiadásért felel • Person in charge of publication: Lovász, László, az MTA elnöke • President of HAS Felelôs szerkesztő • Editor-in-chief: Kindert, Judit Nyomdai munkálatok • Printed by: Kódex Könyvgyártó Kft. 


\section{ABSTRACT}

The historical path to Lagrange's statement of the Principle of virtual velocities has been two-millennium long. It is illustrative of the famous sentence by Bernard de CHARTRES "Nani gigantum bumeris incidentes" [Dwarfs standing on the shoulders of giants], as quoted by John of Salisbury, and shows the laborious process through which such concepts as force, work, etc., seemingly familiar to mechanicists, were elaborated. Since the very beginning, geometrical modelling has been the obvious and commonly accepted basis; the concept of force, whatever its name, was primarily associated with gravity and the fundamental quest has been trying to understand and explain the properties of the simple machines. One may consider that this long-lasting elaboration culminates with Lagrange's statement that opened the way to dual approaches and variational numerical methods but it should not lead us to forget the physical viewpoint in any mathematical model.

\section{TAKING UP A CHALLENGE}

In the $\mathrm{I}^{\mathrm{st}}$ edition of the Méchanique Analitique [I] published in I788 Lagrange had some very extolling words about the principle of virtual velocities (Figure I):

"But this principle is not only very simple and very general in itself; as an invaluable and unique advantage it can also be expressed in a general formula which encompasses all the problems that can be proposed regarding equilibrium. We will expose this formula in all its extent; we will even 
try to present it in a more general way than done usually up to now, and present new applications."

I2 MECHANUE ANALTIQUE. viteffes virtuelles, envifagé différemment, \& dont ils ne différeront que dans l'expreffion.

Au rèfte, ce Principe eft non-feulement en lui-même trèsfimple \& très-général ; ii a de plus l'avantage précieux \& unique de pouvoir fe traduirè en une formule générale qui renferme tous les problêmes qu'on peut propofer fur l'équilibre des corps. Nous allons expofer cette formule dans toute fon étendue; nous tâcherons même de la préfenter d'une manière encore plus générale qu'on ne l'a fait jufqu'à préfent, \& d'en donner des applications nouvelles.

Figure I. Excerpt from Lagrange's Méchanique analitique [I]

But browsing over his Complete works [2] published in I888 one finds that in the subsequent editions, without dimming his enthusiasm for this fundamental principle of Statics, he would be somewhat cautious about the possibility of laying it as a first stone (Méchanique Analitique, section I, Part I, \$I8):

"Regarding the nature of the principle of virtual velocities, it must be recognized that it is not self-evident enough to be settled as a primitive principle" [Quant à la nature du principe des vitesses virtuelles, il faut convenir qu'il n'est pas assez évident par lui-même pour pouvoir être érigé en principe primitif.]

The name of Lagrange shines at the top of the list of the professors of Mechanics at the École Polytechnique (Paris) where he taught from I794, 
when the school was founded, until 1799 (his $\mathrm{I}^{\text {st }}$ successor was Fourier). Some 200 years after Lagrange, Paul GERMAIN, his $27^{\text {th }}$ successor in charge of teaching Mechanics at the École Polytechnique from I973 to I985, did take up the challenge of setting the "Principe des Puissances Virtuelles" as the cornerstone of his synthetic presentation of Mechanics [3]. In the English version of our own textbook for the École Polytechnique [4], where we made the same choice, the wording Principle of virtual work was retained and the corresponding method for the modelling of forces was called Virtual Work Method although the linear forms involved in the statements were explicitly named virtual rates of work.

This wavering regarding the terminology is anything but anecdotic. Many authors have tracked the history and avatars of the concepts of virtual velocities and virtual work: in the Méchanique analitique, Lagrange himself presents what would now be called his own vision of the State of the Art. But it seems that the most comprehensive analysis was made by the French scholar Pierre Duhem, Corresponding Member of the French Academy of Sciences, in the two volumes entitled "Les origines de la Statique" (The Origins of Statics) published in 1905-1906 [5,6], where the laborious emergence of the fundamental concepts of Statics is depicted extensively. It does not fall within the scope of this presentation to go into the details of Duhem's 724 page celebrated contribution nor to attempt summing it up. We aim at selecting some milestones that may be considered as most important in the elaboration of the present developments of the virtual work approach in Mechanics. In this endeavour we have to cope with a difficulty due to the fact that the original texts we refer to were written in ancient Greek, Latin or French, and sometimes in Italian and Flemish: relying on the existing translations in English or to our own we try to overcome this difficulty and avoid ambiguities by inserting the [original words or sentences] when it seems necessary. 


\section{SOME HISTORICAL MILESTONES}

\section{I The simple machines}

When looking for the very roots of Mechanics one inescapably encounters the study of the "simple machines", following the definition given by Renaissance scientists, namely: the lever, sloped (or inclined) plane (ramp), screw, pulley and pulley blocks, wedge (moving ramp)... Aristotle (384-322 B.C.) is usually the first reference. In Quaestionae Mechanicae (Mechanical Problems) [7] and Physicae Auscultationes [8] (Physics), trying to explain the action of a rectilinear lever for instance, he referred to the concept of (motive) "Power" [ $\delta v v a \mu l \varsigma$ or $l \sigma \chi v \varsigma]$ representing the product of the weight of the considered body by its velocity (the ratio of the displacement to the time-span) [9]. Thence the equilibrium of the lever was just stated as the equality (equivalence) of the powers acting at each end, reducing the statics of the lever to the comparison of the velocities of the weights acting at the ends of the lever arms.

"Among the problems included in this class are included those concerned with the lever. For it is strange that a great weight can be moved by a small force, and that, too, when a greater weight is involved. For the very same weight, which a man cannot move without a lever, he quickly moves by applying the weight of the lever. Now the original cause of all such phenomena is the circle; and this is natural, for it is in no way strange that something remarkable should result from something more remarkable, and the most remarkable fact is the combination of opposites with each other. The circle is made up of such opposites, for to begin with, it is composed both of the moving and of the stationary, which are by nature opposite to each other. ... Therefore, as has been said before, there is nothing strange in the circle being the first of all marvels." 
In a completely different approach, Archimedes (287-212 B.C.) would not derive his fundamental statements from any consideration of motion. He simply started from a series of universally accepted "demands" based upon everybody and everyday experience, from which he logically obtained such consequences as the equilibrium of a rectilinear lever. This approach, in $D e$ Planorum Aquilibriis [ı] (A treatise on the equilibrium of planes or their centres of gravity), may be considered as the very foundation of Statics in a way similar to Euclid's Elements for Geometry.

When comparing Aristotle's and Archimedes's approaches one already encounters the two fundamental pathways that were to be followed all along the History of Mechanics: schematically one could say that Archimedes aimed at providing answers to given practical problems based upon a limited number of preliminary demands, while Aristotle would try to formulate a general principle to cope with any possible problem. With the words of Descartes in his criticism of Galileo, Duhem [5] wrote that Archimedes "plainly explains Quod ita sit but no Cur ita sit" ("What" but not "Why") and about Aristotle's analysis":

"This insight is, indeed, the seed from which will come out, through a twenty century development, the powerful ramifications of the Principle of virtual velocities". [Cette pensée, en effet, est la graine d'où sortiront, par un développement vingt fois séculaire, les puissantes ramifications du Principe des vitesses virtuelles].

A similar comment had been made by Fourier in his Mémoire sur la Statique (A Memoir on Statics) [rI]:

"One may add that his writings offer the first insights into the Principle of virtual velocities" [On peut ajouter que ses écrits offrent les premières vues sur le principe des vitesses virtuelles]. 
It is not difficult to see how this distinction is still present now, for instance when teaching is involved, which brings us back to the introductory sentence of this contribution. Anyway it should not be a matter of controversy in such a case when pedagogic arguments should be taken into account considering not only the fact that introducing a general statement is always easier once it has been motivated through a simple example within everyone's grasp, but also the necessity of adapting the teaching methods and contents to their purpose.

The comment by Duhem about Aristotle's insight should not overshadow the fact that it retains a major ambiguity due to his reference to velocities and time as stated explicitly in the following excerpt of Physics (vol. VII, chap. V) [8]:
"Then, $\mathrm{A}$ the movement have moved $\mathrm{B}$ a distance $\mathrm{G}$ in a time $\mathrm{D}$, then in the same time the same force A will move $\mathrm{I} / 2 \mathrm{~B}$ twice the distance $\mathrm{G}$, and in $\mathrm{I} / 2 \mathrm{D}$ it will move $\mathrm{I} / 2 \mathrm{~B}$ the whole distance for $\mathrm{G}$ : thus the rules of proportion will be observed."

\subsection{The laborious emergence of fundamental concepts}

It is clear that we are still very far from Lagrange's statement which is going to be the terminal point of the historical part of this presentation. The concepts need being extracted as an essence through a long lasting trial-and-error process that cannot be presented extensively here following the historical time line and quoting all contributors. The story must be made short.

With Jordanus Nemorarus (XII ${ }^{e}$ A.C.? - his mysterious identity has been thoroughly discussed by Duhem) we encounter two major steps forward in the analysis of the equilibrium of the rectilinear lever or the steelyard [12]:

- Only the vertical component of the circular motion of the weight (pondus) is considered 
- No reference to the duration of the movement or the velocities appears in the statements.

The proof, through geometrical arguments, relies on the implicit assumption that lifting a given weight at a given altitude is equivalent to lifting a weight $k$ times heavier to an altitude $k$ times shorter.

Among the many topics he covered in his manuscripts, which are stored and preserved in the Library of the Institut de France [I3], Leonardo (I43I-I5I9) detailed the properties of the simple machines (Ms. A, E, F, I and $M$ ) that he tried to express through a simple general law (Ms. F) quite similar to Aristotle's statement:

"If a power [puissance] moves a given body along a given length of space during a given time span, it will move half this body during the same time span along twice the given length of space. Or the same power [vertu] will move half this body along the same length of space in half the same time span".

In his analysis of the lever Stevin (1548-1620) followed Archimedes's line of reasoning. He discarded Aristotle's argument based upon circular trajectories with the simple statement that

"Weights that are in equilibrium are motionless and therefore do not move along circles".

which underscores the conceptual difficulty in dealing with the equilibrium of a system by referring to its motion. Nevertheless, for the analysis of the sloped plane Stevin gave a very smart reductio ad absurdum by showing that if the weights in the proper ratio on both sides of the wedge (Figure 2) were not in equilibrium, they would be in perpetual motion, which he considered obviously impossible. Incidentally, Stevin was so proud of his proof that the 
corresponding Figure appears in the cover of his book De Beghinselen der Weeghconst [I4] with the motto "Wonder en is gheen wonder" (No wonder at all) as a refutation of Aristotle's "marvel" (Figure 2).
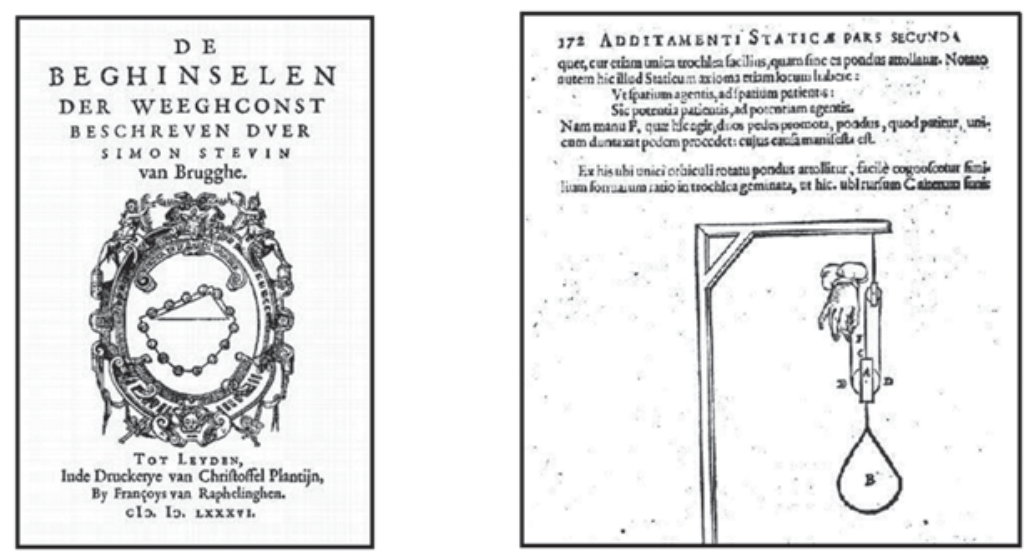

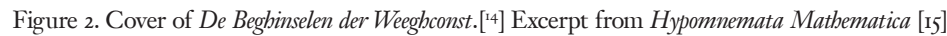

Later on, in Hypomnemata Mathematica [15], when dealing with pulleys and pulley blocks Stevin wrote the following remark (Figure 2):

\section{"Ut spatium agentis, ad spatium patientis:}

Sic potentia patientis ad potentiam agentis"

which expresses that the displacement of the resistance is to the displacement of the power as the power to the resistance. We observe that there is no reference to time in this well balanced Latin sentence (due to his translator from Flemish to Latin) which comes out as some general formulation of the assumption by Jordanus Nemorarus about the solution of the problem of the rectilinear lever. 
In Galileo's (1564-1642) works one encounters several occurrences [1619] of an implicit use of a concept close to virtual work. A famous example is related to the analysis of the sloped plane in Della Scienza Meccanica [16] (Figure 3):

"Finally, let us not overlook the following consideration: as a principle, we said that necessarily, in any mechanical instrument, as much the force was increased via this instrument, as much, on the other hand, one would lose time or velocity. One could feel that this proposal is neither manifest, nor true, in the case that we study ... Thence the weight $F$ moves downwards, drawing the body $E$ on the sloped plane, this body will cover a distance along $A C$ equal to the one described by the weight $F$ in its fall. But this should be observed: it is true that the body $E$ will have covered all the line $A C$ in the time the weight $F$ falls down an equal length; but during this time, the body $E$ will not have moved away from the common centre of weights more than the vertical length $B C$, while the weight $F$, falling down according to the vertical, has dropped a length equal to all the line $A C$. Recall that weights only resist an oblique motion inasmuch as they move away from the centre of the Earth... We can thus say rightly that the travel [viaggio] of the force [forza] $F$ is to the travel [viaggio] of the force [forza] $E$ in the same ratio as the length $A C$ to the length $C B . "$

Although the words "time" and "velocity" do appear in the first quoted paragraph, they do not induce any misunderstanding: the proof was only based upon the concomitant displacements or travels [viaggi] of the weight and the body with respect to the "common centre of weights". Moreover Galileo did not stumble on the difficulty we mentioned earlier about analysing equilibrium through the consideration of motion as shown, for instance, in his analysis of the bearing capacity of a cantilever beam [19], where he almost introduced 


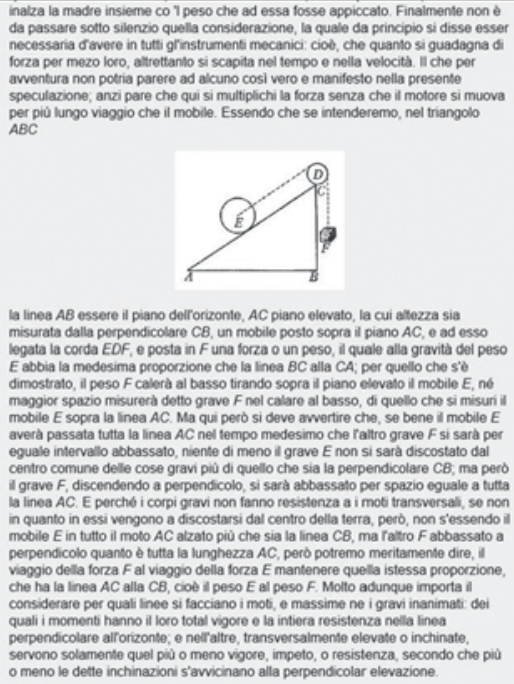

la linea $A B$ essere il piano dellorizonte, $A C$ piano elevato, la cui attezza sia misurata dalla perpendicolare $C B$, un mobile posto sopra il piano $A C$, e ad esso legata la corda EDF, e posta in $F$ una forza o un peso, il quale alla gravita del peso $E$ abbia la medesima proporzione che la inea $B C$ alla $C A$; per quello che s'e dimostrato, il peso $F$ calera al basso tirando sopra il piano elovato il mobile $E$, ne maggior spazio misurera detto grave $F$ nol calare al basso, di quello che si misuri it mobile $E$ sopra la linea $A C$. Ma qui perd si deve awertire che, se bene il mobile $E$ avera passata tutta la linea $A C$ nel tempo medesimo che faltro grave $F$ si sara per eguale intervallo abbassato, niente di meno il grave $E$ non si sara discostato dal centro comune ditle cose grav pie di quello che sia le perpendicolere $C B$, ma pert

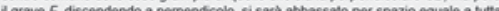
I grave F, discendendo a perpendicolo, si sard abbassato per spazio eguale a tutta la linea $A C$. E perche i corpi gravi non fanno resistenza a i moti transversali, se non in quanto in essi vengono a discostarsi dal centro della terra, pero, non s'essendo il mobile $E$ in tutto il moto $A C$ alzato più che sia la linea $C B$, ma fattro $F$ abbassato a perpendicolo quanto è tutta la lunghezza $A C$, perb potremo meritamente dire, if viaggio della forza $F$ al viaggio della forza $E$ mantenere quella istessa proporzione, che ha la linea $A C$ alla $C B$, cioe if peso $E$ al peso $F$. Molto adunque importa if considerare per quali linee si facciano i mot, e massime ne i gravi inanimati dei quali i moment hanno it loro total vigore e la intiera resistenza nella linea perpendicolare alrorizonte; e netraltre, transversalmente elevate o inchinate, servono solamente quel piè o meno vigore, impeto, o resistenza, secondo che pio o meno le dette inchinazioni s'avvicinano alla perpendicolar elevazione

Figure 3. Excerpt from Galileo Galilei Le Mecaniche [17]

the concept of virtual motion in a thought-experiment for designing the rectangular lever that would model the built-in beam and be analysed from the statical viewpoint:

"...It is clear that, if the cylinder breaks, fracture will occur at the point $\mathrm{B}$ where the edge of the mortise acts as a fulcrum for the lever $\mathrm{BC}$, to which the force is applied; the thickness of the solid BA is the other arm of the lever along which is located the resistance..."

\subsection{Descartes, Wallis}

Through this incomplete historical review we note, at this stage, the absence of well-defined concepts, although the word "Travail" [Work] had already 
been first introduced in French with its present meaning in Mechanics by SALOMON de CAUS (1576-1630) in his book Les raisons des forces mouvantes [20], and the ambiguous and controversial reference to displacements or velocities.

The correspondence of Descartes (1596-1650), as published by Adam and Tannery [21-23], shows through many examples that he had a much clearer vision of a virtual velocity principle than his predecessors or contemporaries. He stated it plainly, answering a letter from Constantin Huygens (Christian's father) on October 5, 1637 (Figure 4) about the fundamental principle of the simple machines in its common form:

"The invention of all these machines is founded on one principle, which is that the same force which can lift a weight, for example of Ioo pounds, up to two feet, can also lift a weight of 200 pounds up to one foot, or a weight of 400 pounds up to half a foot...”

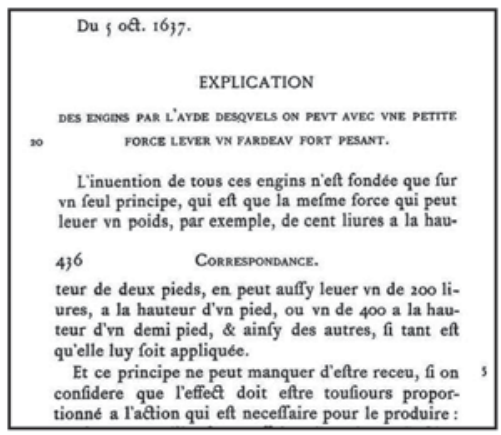

LE PLAN INCLINE.

Si, n'ayant qu'affez de force pour leuer 100 liures, on veut neantmoins leuer le cors F, qui en pefe 200 , a la hauteur de la ligne B A, il ne faut que le tirer ou rouller le long du plan incliné $\mathrm{C} \mathrm{A}$, que ie fuppofe deux fois aufry long que la ligne A B; car, par ce moyen, pour le faire paruenir au point $\mathrm{A}$, on $\mathrm{y}$ employera la force qui eft requife pour faire monter too liures deux fois auffy haut. Et d'autant qu'on aura fait ce plan C A plus incliné, d'autant aura-t-on befoin de moins de force pour leuer le poids $F$ par fon moyen.

Figure 4. Excerpt from Descartes's letter to Constantin Huygens [2I] 
which expresses the conservation of the product of the load by its vertical displacement; in the following letter he examined such simple machines as the pulley, sloped plane, wedge, etc. within this framework. In a letter to Mersenne (July I3, I638) Descartes [22] insisted on the fact that the displacements to be considered are infinitesimal (Figure 5), which is obviously a major step forward as regards the final formulation of the principle:

"From this it follows evidently that the gravity relative to a given body, or equivalently the force to be exerted to sustain it or prevent it from going down, when it is in a given position, should be measured by means of the beginning of the movement that would be done by the power which sustains it either for lifting it or following it if it went down."

cent a la hauteur de deux pieds. Et il fuit euidenment de cecy que la pefanteur relative de chafque cors, ou ce qui eft le mefme, la force qu'il faut employer pour

10 le foutenir \& empefcher qu'il ne defcende, lors qu'il eft en certaine pofition, fe doit mefurer par le commencement du mouuement que deuroit faire la puiffance qui le fouftient, tant pour le hauffer que pour le fuiure s'il s'abaiffoit. En forte que la proportion qui
Notez que ie dis commencer a defcendre, non pas fimplement defcendre, a caufe que ce n'eft qu'au commencement de cete defcente a laquelle il faut prendre 3o garde. En forte que fi, par exemple, ce poids $F$ n'eftoit

Figure 5. Excerpt from Descartes's letter to Mersenne [22]

In order to make himself clearer he added a few lines below:

"Note that I say begin to go down and not simply go down, because it is only the beginning of the descent that must be taken into account".

Apart from the infinitesimal character of the displacements that must be considered, one should note that Descartes in the French wording makes use of the conditional or potential mode for the verb "par le commencement du mouvement que devroit [devrait] faire la puissance qui le soustient [soutient]" which is already an introduction to the virtuality of these displacements, thus countering Stevin's objection about the contradiction between equilibrium 
and motion. Finally, let us quote a short sentence in a letter which is usually considered as having been sent to Boswell in I646 [23], where Descartes discarded actual velocities as the cause of the properties of such simple machines as the lever in the Aristotelian way (Figure 6):

"I do not deny the material truth of what Mechanicists usually say, namely that the higher the velocity of the longer arm of the lever compared with the shorter arm, the smaller the force necessary to move it; but I do deny that velocity or slowness be the cause of this effect."

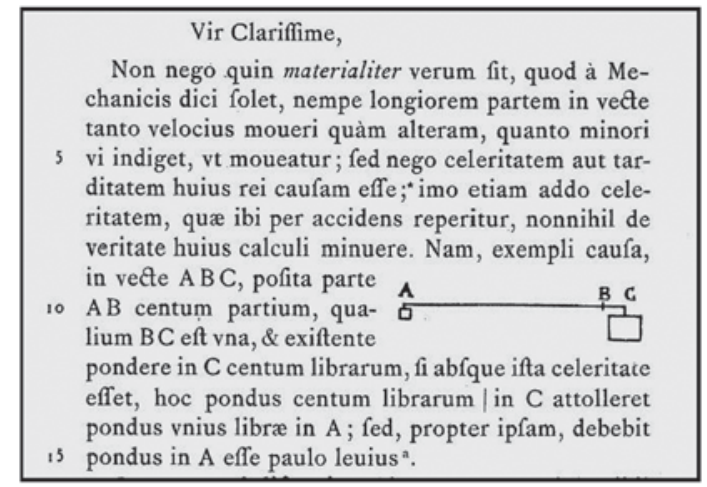

Figure 6. Excerpt from Descartes' letter to Boswell [23]

In other words, referring to time or velocities is not erroneous but irrelevant.

From all the analyses that have been made of Descartes's writings devoted to Statics it seems that they were only concerned with gravity forces. His fundamental statement was generalized by Wallis (1616-1703) in Mechanica: sive, De Motu [24] (Figure 7) to deal with any kind of forces with the proper definition of their forward or backward movements: 
"And, as a general rule, the forward or backward movements of motor forces whatsoever [virium motricium quarumcunque] are obtained from the products of the forces by their forward or backward movements estimated along the directions of these forces."

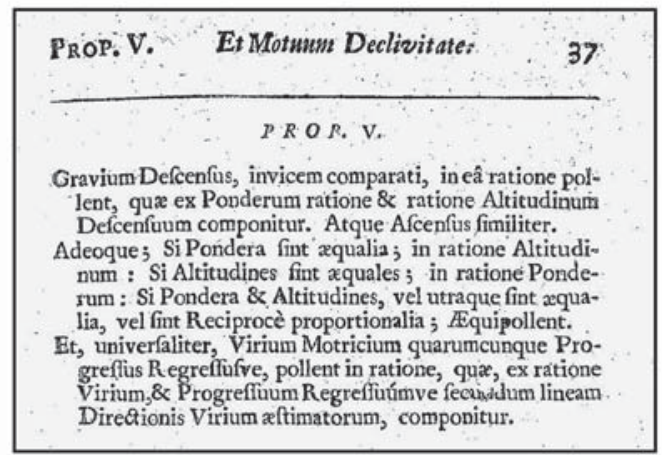

Figure 7. Excerpt from Wallis' Mechanica: sive, De Motu. Pars I [24]

\subsection{Bernoulli (Johann)}

Thanks to Pierre Varignon in his Nouvelle Mécanique ou Statique, [25] (II, ix, I74) we have the exact wording of the letter Johann Bernoulli (I667-1748) sent him on January 26, 1717 (Figure 8). In this letter Bernoulli gave the first definitions of the words Energy [Énergie] and Virtual Velocities [Vitesses virtuelles] in the case of a small rigid body motion. Defining Virtual Velocities, he considers small rigid body movements and the components of the corresponding small displacements of the forces along their lines of action:

"Imagine several different forces which act according to various trends or directions to maintain a point, a line, a surface or a body in equilibrium. Imagine that a small movement, either parallel to any direction or about 
any fixed point be imposed to all this system of forces. It will be easy for you to understand that in this movement each of these forces advances or moves back in its direction, unless one or more of these forces have their own tendencies [tendances] perpendicular to the direction of the small movement; in which case this force or these forces would not advance nor move back; because these movements forward or backward, which are what I call virtual velocities, are just what the quantities in which each tendency line increases or decreases in the small movement."

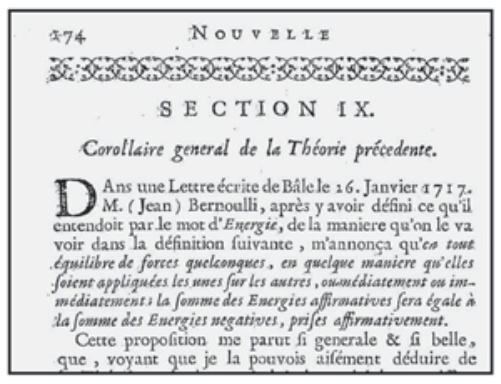

\begin{tabular}{|c|}
\hline 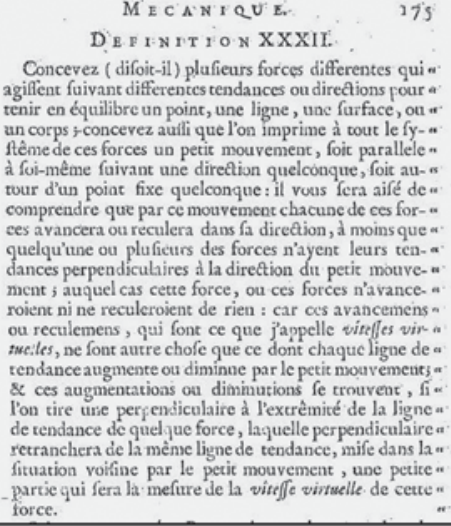 \\
\hline
\end{tabular}

Figure 8. Excerpt from Varignon's Nouvelle Mécanique ou Statique

He then defines the Energy of each force as the product of the considered force by its virtual velocity in the movement, either "affirmative" or "negative" depending on whether the force moves forward or backward: in fact just the definition of the work by the considered force in the small displacement of its point of application. With these definitions Bernoulli issues the general statement that [in any small rigid body motion]: 
"For any equilibrated system of forces... the sum of the affirmative energies will be equal to the sum of negative energies counted positive."

In a footnote on page 268 of the $2^{\text {nd }}$ volume of Les Origines de la Statique, Duhem could not help lamenting that Bernoulli adopted the terminology "vitesses virtuelles" [virtual velocities] instead of virtual displacements since velocities have nothing to do in that matter, and also that this terminology had been retained by many authors. As a response to that criticism one may argue now that this terminology makes it impossible to forget about the infinitesimal character of the quantities involved. The word virtual qualifying those velocities may be considered sufficient to recall that they are no velocities at all but just test functions in the mathematical sense of functional analysis. It could be suggested that the term "virtual velocities" be understood as a whole to name these functions.

\section{Lagrange}

Lagrange (1736-1813) devoted many writings to the formulation of the Principle of virtual velocities. In the $\mathrm{I}^{\text {st }}$ edition of the Méchanique analitique [I], after defining the concepts of Force which he also named Power [puissance] and virtual velocities, he gave a generalised statement of the principle of virtual velocities where the small movements involved were no longer restricted to rigid body motions as in Bernoulli's statement (Figure 9):

"If a system of bodies or points, each of them being submitted to arbitrary forces, is in equilibrium, and if this system is given a small unspecified movement, in which each point moves along an infinitely small distance, which is its virtual velocity, the sum of the products of each force by the distance travelled by its point of application along the direction of the force, will always be equal to naught, with the small distances being 
counted positive when they are travelled in the direction of the force and negative in the opposite direction."

\footnotetext{
Le Principe des viteffes virtuelles peutêtre rendu très-général de cette maniere :

Si un fyftême quelconque de tant de corps ou points que lon veut tires, chacun par des puiffances quelconques, eft en équilibre, Ė qu'on donne à ce fyftême un petit mouvement quelconque, en veriu duquel chaque point parcoure un efpace infiniment petit qui exprimera fa vitefje virtuelle; la fomme des puiffances, multipliées chacune par l'efpace que le point où elle eft appliquée, parcourt fuivant la direction de cette même puiffance, fera toujours égale à zero, en regardant comme pofutifs les petits efpaces parcourus dans le fens des puiffances, \& comme négatifs les efpaces parcourus dans un fens oppofé.
}

Figure 9. Excerpt from Lagrange's Méchanique analitique [I]

A few years later, in a paper published in the fournal de lécole polytechnique [26], Lagrange expressed his dissatisfaction as to the principle of virtual velocities being usually derived from the principles of composition of forces and equilibrium of the lever since he considered them not evident enough. He thus presented a new proof based upon the pulley block equilibrium principle, where the main thrust is to consider that the forces applied to each body of a system (as in the preceding references, the term "body" refers to a material point) are exerted by means of a weight acting at one end of an inextensible, flexible and weightless string through as many fixed and mobile pulley blocks as necessary, the other end of the string being fixed as shown in Figure io (which is an attempt to illustrate this description since, as a rule, Lagrange did not provide any figure). Then the argument proceeds from the consideration that equilibrium of the system is reached in the state where any infinitely small displacement of each body does not produce any downward movement of the active weight at the end of the string. 


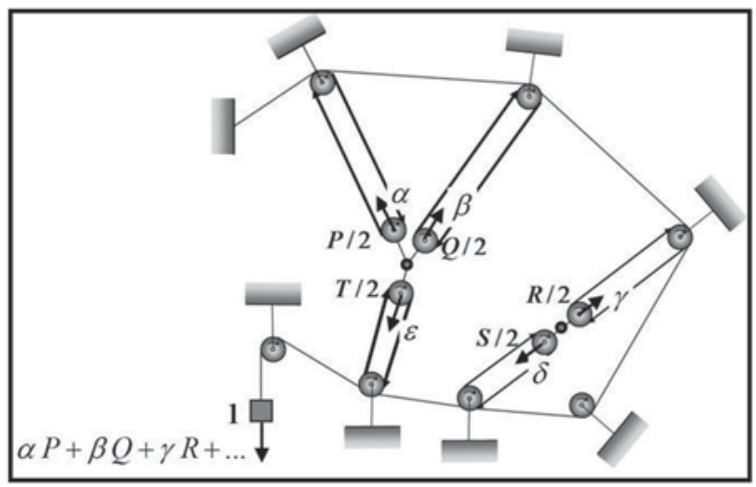

Figure ı. This figure is an attempt to illustrate Lagrange's approach to the principle of virtual velocities through a system of pulley blocks, following his description in [I]

More precisely, using the notations Lagrange adopted in the subsequent editions of the Méchanique analitique where he reproduced this approach, the forces acting on the bodies are obviously assumed commensurable, with even integer values $P, Q, R \ldots$, the active weight at the end of the string being taken as a unit. This implies that the numbers of pulleys in the corresponding pulley blocks are respectively $P / 2, Q / 2, R / 2 \ldots$ It must also be noted that no geometrical constraints, either internal or external, are imposed on the bodies of the system. Infinitesimal arbitrary displacements of the bodies result in the distances between the mobile pulley blocks and the corresponding fixed ones being reduced by the quantities $\alpha, \beta, \gamma, \ldots$ respectively. As a consequence, the active weight would move downward along the infinitesimal distance $\alpha P+\beta Q+\gamma R+\ldots$ Writing that equilibrium of the system implies no downward motion of the active weight results in

$$
\alpha P+\beta Q+\gamma R+\ldots=0
$$

"which is precisely the analytic expression of the general principle of virtual velocities". 
Whatever its ingenuity, this proof obviously still suffers some shortcomings which do not appear in the proof given by Fourier in the same issue of the Fournal de lécole polytecbnique [II]. Anyhow, Eq. (I) is the starting point of an important development in the subsequent editions of the Méchanique analitique regarding geometrical constraints.

Eq. (I) may be written in the general differential form with respect to the coordinates $\left(x, y_{i} z_{i}\right)$ of each body (index $\left.i\right)$ of the system:

$$
P \mathrm{~d} p+Q \mathrm{~d} q+R \mathrm{~d} r+\ldots=0
$$

where the differentials $\mathrm{d} p, \mathrm{~d} q, \mathrm{~d} r, \ldots$ are typically written

$$
\mathrm{d} p=\frac{\partial p}{\partial x_{i}} \mathrm{~d} x_{i}+\frac{\partial p}{\partial y_{i}} \mathrm{~d} y_{i}+\frac{\partial p}{\partial z_{i}} \mathrm{~d} z_{i}
$$

with the index $i$ referring to the body concerned by the considered force. In the case of no geometrical constraints Eq. (2) is valid $\forall \mathrm{d} x_{i}, \mathrm{~d} y_{i}, \mathrm{~d} z_{i}, \forall i$. This leads to the equilibrium equations of the system by equating all the coefficients of $\mathrm{d} x_{i}, \mathrm{~d} y_{i}, \mathrm{~d} z_{i}, \forall i$ to zero.

Assuming the geometrical constraints that may be imposed to the evolution of the bodies to be written as linear forms of the differentials $\mathrm{d} x_{i}, \mathrm{~d} y_{i}, \mathrm{~d} z_{i}, \forall i$ being equal to zero:

$$
\mathrm{d} L=0, \mathrm{~d} M=\mathrm{d} N=0, \ldots
$$

Lagrange remarks, from the theory of linear equations, that writing Eq. (2) with Eq. (3) under the mathematical constraints (4) on $\mathrm{d} x_{i}, \mathrm{~d} y_{i}, \mathrm{~d} z_{i}, \forall i$ is equivalent to writing

$$
P \mathrm{~d} p+Q \mathrm{~d} q+R \mathrm{~d} r+\ldots+\lambda \mathrm{d} L+\mu \mathrm{d} M+v \mathrm{~d} N+\ldots=0, \forall \mathrm{d} x_{i}, \mathrm{~d} y_{i}, \mathrm{~d} z_{i}, \forall i
$$

where $\lambda, \mu, v$ are indeterminate. 
To this method Lagrange gave the name of Méthode des multiplicateurs (Multiplier Method) while referring to Eq. (5) as the general equation of equilibrium and explaining how to handle it in order to obtain the solution to the equilibrium problem.

But the most important step forward came out from his noting the mathematical similarity of the $\lambda \mathrm{d} L, \mu \mathrm{d} M \ldots$ terms with the $P \mathrm{~d} p, Q \mathrm{~d} q \ldots$ ones and giving a mechanical significance to the Lagrange multipliers. Assuming $\mathrm{d} L$ to be the differential of a function $L$ of the coordinates of the bodies in the system, the term $\lambda \mathrm{d} L$ is written

$$
\lambda \mathrm{d} L=\lambda \frac{\partial L}{\partial x_{i}} \mathrm{~d} x_{i}+\lambda \frac{\partial L}{\partial y_{i}} \mathrm{~d} y_{i}+\lambda \frac{\partial L}{\partial z_{i}} \mathrm{~d} z_{i}, i=1,2, \ldots,
$$

which is quite similar to Eq. (3) but for the fact that the coordinates of more than one body may be involved. Thence Lagrange's statements:

"It comes out then that each geometrical constraint equation is equivalent to one or several forces acting on the system, along given directions or, as a general rule, tending to vary the values of the given functions; so that the same state of equilibrium will be obtained for the system, either using these forces or the constraint equations. And here one encounters the metaphysical reason why introducing the terms $\lambda \mathrm{d} L+\mu \mathrm{d} M+\ldots$ in the general equilibrium equation makes it possible to treat this equation as if all bodies were completely free." And further on: "Conversely, these forces may be substituted for the geometrical constraint equations in such a way that, using these forces the constituent bodies of the system will be considered as completely free without any constraint... In proper words, these forces stand as the resistances that the bodies should meet for being linked to each other or due to the obstacles that may impede their motion; or rather, these forces are precisely the resistances, which must be equal and opposite to the pressures exerted by the bodies." 
The scalars $\lambda, \mu, v$ are now known as the Lagrange multipliers associated with the corresponding constraints.

These statements are crucial: one may say that they introduce and define binding and internal forces from the given geometrical constraints, either external or internal, through the concept of duality. This actually opened the way to the formulation of the principle that is used now when modelling mechanical systems.

One may also remark that although Lagrange's proof assumes the geometrical constraints, either external or internal, to be written as linear forms of $\mathrm{d} x_{i}, \mathrm{~d} y_{i}, \mathrm{~d} z_{i}, \forall i$ being equated to zero, the final interpretation of the scalars $\lambda, \mu, v$ related to the resistances associated with these geometrical constraints yields the possibility of treating geometrical constraints that are expressed as inequalities such as $\mathrm{d} L \geq 0$ and/or $\mathrm{d} M \geq 0$ (as for unilateral support for instance): the geometrical constraints are still considered as equalities, which we may call "bilateral", $\mathrm{d} L=0, \mathrm{~d} M=0$, and inequalities $\lambda \leq$ $0, \mu \leq 0$ are imposed on $\lambda, \mu$ as conditions on the "resistances". This maintains the essential point that Eq. (5) is written $\forall \mathrm{d} x_{i}, \mathrm{~d} y_{i}, \mathrm{~d} z_{i}, \forall i$.

\section{THE VIRTUAL WORK METHOD}

Now we may try to sketch out the virtual work model building method in Continuum mechanics.

\section{I Geometrical description}

The starting point is the geometrical description of the system under consideration where no geometrical constraint, either external or internal, is taken into account. At this stage the mechanicist will first consider the main geometrical features of the system and also rely on his intuition about the 
modelling scale that seems appropriate to the type of results he is looking for. As an example, such a practical system as a reinforced concrete slab may be modelled either as a $2 \mathrm{D}$-continuum or as a $3 \mathrm{D}$ one with full details about its constituent elements, depending on the precision level required by its design and dimensioning. This description defines the elements of the system at the chosen scale through the parameters that describe its configuration at a given instant of time.

For instance, in the case of the classical $3 \mathrm{D}$-continuum the elements are the "particles", kind of "diluted material points", and the corresponding parameters which describe the geometrical state of the system are just the positions (coordinates) of its constituent particles. A generalized $3{ }_{3} \mathrm{D}$-continuum may be built up on the same geometrical basis where the parameters defining the geometrical state of a particle are not only its coordinates but also the orientation of an attached "microstructure" introduced to convey some information about the underlying micro-scale (micropolar media). This is also the process for passing from the $\mathrm{ID}$-wire model to the $\mathrm{ID}$-beam model, or from the $2 \mathrm{D}$-membrane model to the $2 \mathrm{D}$-plate model.

The geometrical description also includes the definition of the subsystems which are delineated in the system and composed of elements considered as interacting with the external world and the rest of the system.

\subsection{Virtual motions}

Virtual motions of the system in a given configuration are simply defined as infinitesimal variations of the parameters describing its geometrical state. No geometrical constraint being taken into account, due to the linearity associated with the infinitesimal character, these virtual motions generate a vector space. 
As it has been underscored along the historical path, no notion of time whatsoever is involved in this definition. Nevertheless, in order to enhance their infinitesimal character, it is common practice to use the term "virtual velocity fields" when referring to virtual motions. It must also be observed that actual velocity fields for the system are special cases of virtual velocity fields; as a matter of fact, for the practical relevance of the model to be built up, it is essential that the vector space of virtual motions should encompass all the possible actual motions of the system.

\section{$4 \cdot 3$ Continuity}

The concept of a Continuum to be introduced in the model is the mathematical formulation of the physical intuition that neighbouring particles have similar evolutions and remain neighbours throughout, as opposed to a set of loose particles. It implies that the mathematical rendering of this concept comes out as regularity conditions to be imposed on the virtual velocity fields, namely continuity and continuous differentiability. Once the force modelling process is completed, piecewise continuous, continuously differentiable virtual velocity fields will be taken into consideration (this can also be done straightforwardly within the framework of the Theory of distributions).

\subsection{Statement of the Principle of Virtual Work}

As a generic notation virtual velocity fields will be denoted $\underline{\hat{U}}$. All statements and equations are written in a Galilean frame. The system under consideration is denoted $S$; the concept of subsystem, denoted $S^{\prime}$, part of $S$, is introduced: for such a subsystem, the external forces are exerted from outside $S$ and by the particles of $S$ from outside $S$ '. In order to shift from the Statics viewpoint to the Dynamics one, d'Alembert's principle is applied which introduces the quantities of acceleration. Then the Principle of Virtual Work is written: 
In a Galilean frame,

- $\quad$ For the system $S$

(7)

$$
\left\{\begin{array}{l}
\forall \underline{\hat{U}} \text { virtual motion of } \mathcal{S}, \mathcal{P}_{\mathrm{e}}(\hat{\hat{U}})+\mathcal{P}_{\mathrm{i}}(\underline{\hat{U}})=\mathcal{A}(\underline{\hat{U}}) \\
\forall \underline{\hat{U}} \text { rigid body virtual motion of } \mathcal{S}, \mathcal{P}_{\mathrm{i}}(\underline{\hat{U}})=0
\end{array}\right.
$$

- For any subsystem $S$,

(8)

$$
\left\{\begin{array}{l}
\forall S^{\prime} \subset \mathcal{S}, \\
\forall \underline{\hat{U}} \text { virtual motion of } \mathcal{S}^{\prime}, \mathcal{P}_{\mathrm{e}}^{\prime}(\hat{\underline{U}})+\mathcal{P}_{\mathrm{i}}^{\prime}(\underline{\hat{U}})=\mathcal{A}^{\prime}(\underline{\hat{U}}) \\
\forall \underline{\hat{U}} \text { rigid body virtual motion of } \mathcal{S}^{\prime}, \mathcal{P}_{\mathrm{i}}^{\prime}(\underline{\hat{U}})=0
\end{array}\right.
$$

In these equations, $\mathcal{P}_{\mathrm{e}}(\underline{\hat{U}}), \mathcal{P}_{\mathrm{i}}(\underline{\hat{U}}), \mathcal{A}(\underline{\hat{U}})$ for $S$ and $\mathcal{P}_{\mathrm{e}}^{\prime}(\underline{\hat{U}}), \mathcal{P}_{\mathrm{i}}^{\prime}(\underline{\hat{U}}), \mathcal{A}^{\prime}(\underline{\hat{U}})$, for $S^{\prime}$ are continuous linear forms on the vector space of virtual motions of $S$ (resp. $S^{\prime}$ ).

$\mathcal{P}_{\mathrm{e}}(\underline{\hat{U}})$ and $\mathcal{P}_{\mathrm{e}}^{\prime}(\underline{\hat{U}})$ stand for the virtual rates of work by the external forces for $S$ and $S^{\prime}$ respectively; $\mathcal{P}_{\mathrm{i}}(\underline{\hat{U}})$ and $\mathcal{P}_{\mathrm{i}}^{\prime}(\hat{\underline{U}})$, for the virtual rates of work by the internal forces; $\mathcal{A}(\underline{\hat{U}})$ and $\left.\mathcal{A}^{\prime}(\underline{\underline{U}})\right)$, for the virtual rates of work by the quantities of acceleration.

Although, at a first glance, Eqs (7) does not appear as straightforwardly derived from Lagrange's statement, comparing the first line of Eqs (7) with Eq. (5) points out that:

- The constituent particles of the system are "considered as completely free without any constraint" since this equation is written $\forall \underline{\hat{U}}$ virtual motion of $S$.

- The virtual rate of work by the external forces for $S$ contains the virtual rate of work by the reactions associated with the geometrical 
constraints due to "the obstacles that may impede" the motion: the counterpart of the $\lambda \mathrm{d} L$ terms.

- The rate of work by the internal forces is nothing else than the counterpart of the $\mu \mathrm{d} M$ terms standing for the "resistances" that the particles "should meet for being linked to each other".

The second line of Eqs (7), dualised form of the Law of mutual actions, expresses the important characteristic of internal forces. Through a careful reasoning, it may be described as the general principle of frame indifference of the work done by the internal forces: recalling that virtual velocity fields are no velocity at all, frame indifference is only concerned with actual velocity fields of the system, but writing down the frame indifference condition for the rate of work by the internal forces results in the purely mathematical condition $\forall \underline{U}$ rigid body motion of $S, \mathcal{P}_{\mathrm{i}}(\underline{U})=0$

where the considered vector space of rigid body motions is identical to the one in the second line of Eqs (7).

Eqs (8) are related to the subsystems of $\boldsymbol{S}$ and their statements seem identical to Eqs (7) due to the similarity of notations used for the linear forms. It should not obscure the key difference between the system, which can be understood in a concrete way, and its subsystems which are mere intellectual constructions like thought-experiments. This difference is especially noteworthy regarding the expressions of the linear forms $\mathcal{P}_{\mathrm{e}}(\underline{\underline{\hat{U}}})$ and $\mathcal{P}_{\mathrm{e}}^{\prime}(\underline{\underline{U}})$ as it appears when applying the virtual work method: external forces for $S$ can then be considered as given or known, supported by an experimental base, whereas for $S$ ' the expression of the external forces as cofactors in the linear form $\mathcal{P}_{\mathrm{e}}^{\prime}(\underline{\hat{U}})$ depends on hypotheses and intuitive judgement, due to the contribution of the external forces exerted by the particles of $S$ from outside $S$ '. 
It is worth noting that the terminology Principle of Virtual Work has been substituted for the historical one: Principle of virtual velocities. It emphasises the fact that the virtual velocities, whatever the historical difficulty of their definition, are the implements of the principle while the governing quantities in its implementation are the virtual works - or, more precisely, virtual rates of work - done by the external and internal forces and the quantities of acceleration. This will appear even more clearly in the Virtual Work Method.

\subsection{The Virtual Work Method}

The Virtual work method takes the principle of virtual (rates of) work as a primitive principle.

The geometrical description of the system being completed as in \$4.I, implying the definition of the vector spaces of the virtual motions for the system and its subsystems, the implementation of the method consists primarily in writing the expressions of the virtual rates of work as continuous linear forms on these vector spaces.

- Writing down $\mathcal{A}(\underline{\underline{\hat{U}}})$ and $\left.\mathcal{A}^{\prime}(\underline{\hat{U}})\right)$ proves quite easy. The quantities of acceleration that are the cofactors in these linear forms are the product of the mass of the particles by their acceleration in a real motion.

- The model chosen for the external forces for $\boldsymbol{S}$ can be considered as given; it is guided by experience and is consistent with the modelling scale and the type of expected results. It provides the cofactors in the linear form $\mathcal{P}_{\mathrm{c}}(\hat{\underline{U}})$.

- Regarding the external forces for a subsystem, since it is only the result of a thought-experiment, one cannot rely on experience but essentially on intuition; the corresponding continuous linear form 
will be given some expression to be determined as a result of the method.

- Expressions for the continuous linear forms $\mathcal{P}_{\mathrm{i}}(\underline{\hat{U}})$ and $\mathcal{P}_{\mathrm{i}}^{\prime}(\underline{\hat{U}})$, virtual rates of work by the internal forces for the system and subsystems, are also the fruit of hypotheses which are constrained by the condition of frame indifference in Eqs (7) and (8).

Then, from the arbitrary character of the continuous and continuously differentiable velocity fields, the $\mathrm{I}^{\text {st }}$ Eq. (7) yields the field and boundary equations of motion for the system. This is, in fact, the classical mathematical process when dealing with a dual formulation. Applied to any subsystem, the same process determines the external forces acting on this subsystem from the knowledge of the internal forces already determined in $S$.

It must be clear from this description that, albeit being systematic and structured, the Virtual work method is in no way axiomatic. Hypotheses and choices are made all along in the light of experience, intuition and also the type of mathematical model that seems suited to the perceived "physical reality". Validation of the model is obviously the ultimate step of the process.

The principal advantage of the method lies in its being systematic, making it possible through Eqs (7) and (8) to ensure that the various hypotheses made when writing down the linear forms are consistent with each other. This means that the corresponding expressions must be mutually consistent from a mathematical standpoint. This systematic character of the method is also an advantage when, letting aside classical models, one is trying to elaborate more original or innovative ones [27]. Once again the required modelling consistency is directly provided by the method. 


\section{FINAL COMMENTS}

The difficulties that have been pointed out along the historical path in the emergence of such concepts as force, work, virtual velocities and virtual work should not be overlooked now when these concepts are first introduced in a pedagogical presentation. Fundamentally, it is the very concept of modelling that must be made familiar progressively. From this standpoint, the virtual work method starts clearly from the geometrical description which is certainly the easiest part of modelling as it appears close to the physical perceptible reality. Writing down the expressions of the linear forms for the implementation of the method enhances the fact that the modelling of forces cannot be disconnected from the geometrical modelling as it might sound from classical presentations where the Theorem of virtual work appears suddenly, as if it were a surprise, at the end of the construction of the force model. This being said, the virtual work method is not exclusive of any other; on the contrary its understanding and appropriation are improved by making the links with alternative methods. From this understanding it becomes easier to shift from one model to more sophisticated ones or to work with embedded or nested models.

Then, following Lagrange, it is hard to believe that the statement of the principle of virtual work can be directly introduced: some kind of "motivating" example on a simple and well-known model will make it acceptable and, at the same time, allow demonstrating how the dual formulation can be handled to yield the primal one. 


\section{REFERENCES}

[I] Lagrange, J-L. (I788): Mechanique Analitique. À Paris, chez la Veuve Desaint, rue du Foin S. Jacques.

[2] Lagrange, J-L. (I888): Euvres complètes. Vol. II. Gauthier-Villars, Paris, I888.

[3] Germain, P. (1986): Mécanique (Mechanics). Ellipses, Paris.

[4] Salençon, J. (200I): Handbook of Continuum Mechanics. Springer-Verlag, Berlin, Heidelberg, New York.

[5] Duhem, P. M. M. (1905): Les origines de la Statique vol. I, Hermann, Paris.

[6] Duhem, P. M. M. (I906): Les origines de la Statique vol. 2, Hermann, Paris.

[7] Aristotle: Quaestionae Mechanicae. (Mechanical Problems). http://penelope.uchicago.edu/ Thayer/E/Roman/Texts/Aristotle/Mechanica*.html

[8] Aristotle: Physicae Auscultationes. (Lectures on nature). Translated by R. P. Hardie and R. K. Gaye. http://classics.mit.edu/Aristotle/physics.7.vii.html.

[9] De Groot, J. (2008): Dunamis and the Science of Mechanics: Aristotle on Animal Motion. Fournal of the History of Philosophy, vol. 46, I,43-68.

[ı] Archimedes: De Planorum Aquilibriis. (A treatise on the equilibrium of planes or their centres of gravity).

[II] Fourier, J. (I797): Mémoire sur la statique contenant la démonstration du principe des Vitesses virtuelles, et la théorie des Momens. Fournal de lécole polytechnique. Ve cahier, Tome II, prairial an VI, pp. 20-6o, Imprimerie de la République, Paris.

[I2] Jordanus Nemorarus: Elementa fordani super demonstrationem ponderis

[13] Leonardo da Vinci (1487-1508): Les Manuscrits de Léonard de Vinci. Ms $A$-M. Bibliothèque de l'Institut de France, Paris.

[14] Stevin, S. (1586): Beghinselen der Weeghconst. Leyden.

[15] Stevin, S. (I605): Hypomnemata mathematica. (Additamenti Staticæ pars secunda: de Trochleostatica). Lugodini Batavorum, ex officina Ioannis Patii, academiæ Typographi.

[ı] Galileo Galilei (ı634): Les Méchaniques. Translation by Mersenne of Della Scienza Meccanica, Ravenna (I649).

[ı7] Galileo Galilei (I599): Le Mecaniche. Della vite. http://it.wikisource.org/wiki/Le_ mecaniche/Della_vite.

[I8] Galileo Galilei (1638): Discorsi e dimostrazioni matematiche intorno a duo nuove scienze attenenti alla Meccanica, ed ai movimenti locali. Elsevirii, Leyden.

[ı9] Galileo Galilei (1638): Dialogues concerning two new sciences. crew, H. \& salvio, A. transl., Dover, New York, I954.

[20] Salomon de Caus (1615): Les raisons des forces mouvantes avec diverses machines tant utiles que plaisantes... Jan Norton, Francfort.

[21] Descartes, R.: Correspondance.I (April I622-February I638); Published by Adam, C. and Tannery, P., I969. Librairie philosophique J. Vrin, Paris, I988. 
[22] Descartes, R.: Correspondance.2 (March I638-December I639); Published by Adam, C. and Tannery, P., 1969, Librairie philosophique J. Vrin, Paris, 1988.

[23] Descartes, R.: Correspondance.4 (July i643-April i647); Published by Adam, C. and Tannery, P., 1969. Librairie philosophique J. Vrin, Paris, 1988.

[24] Wallis, J. (1670): Mechanica: sive, De Motu, Tractatus Geometricus. Pars Prima.

[25] Varignon, P. (1725) - Nouvelle Mécanique ou Statique, vol. II. Claude Jombert, Paris.

[26] Lagrange, J-L. (1797): Sur le principe des vitesses virtuelles. Fournal de l'école polytechnique. $V^{E}$ cahier, Tome II, prairial an VI, pp. II5-II8, Imprimerie de la République, Paris.

[27] Frémond, M. (2002): Non-Smooth Thermomechanics. Springer-Verlag, Berlin, Heidelberg, New York. 




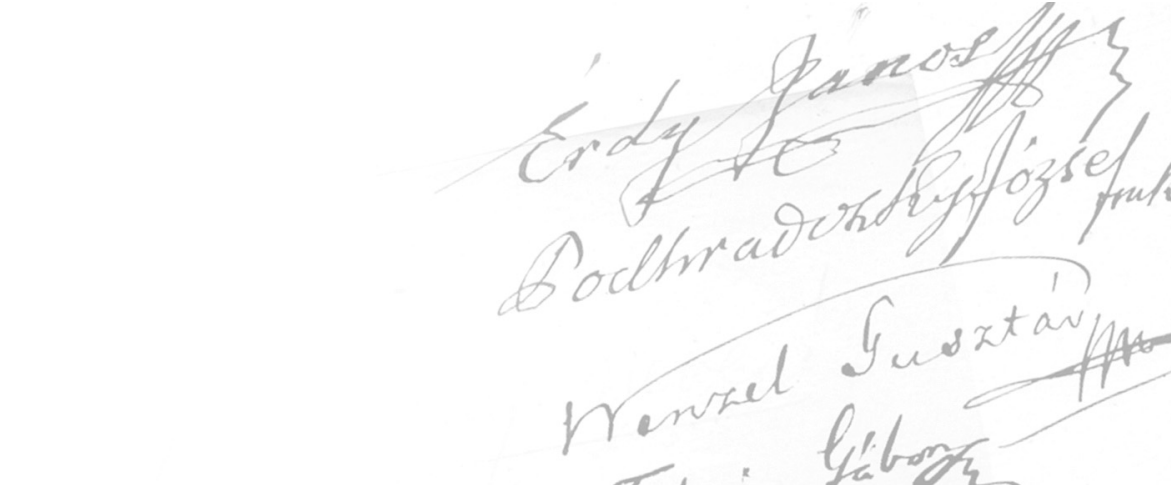

Fation latrog

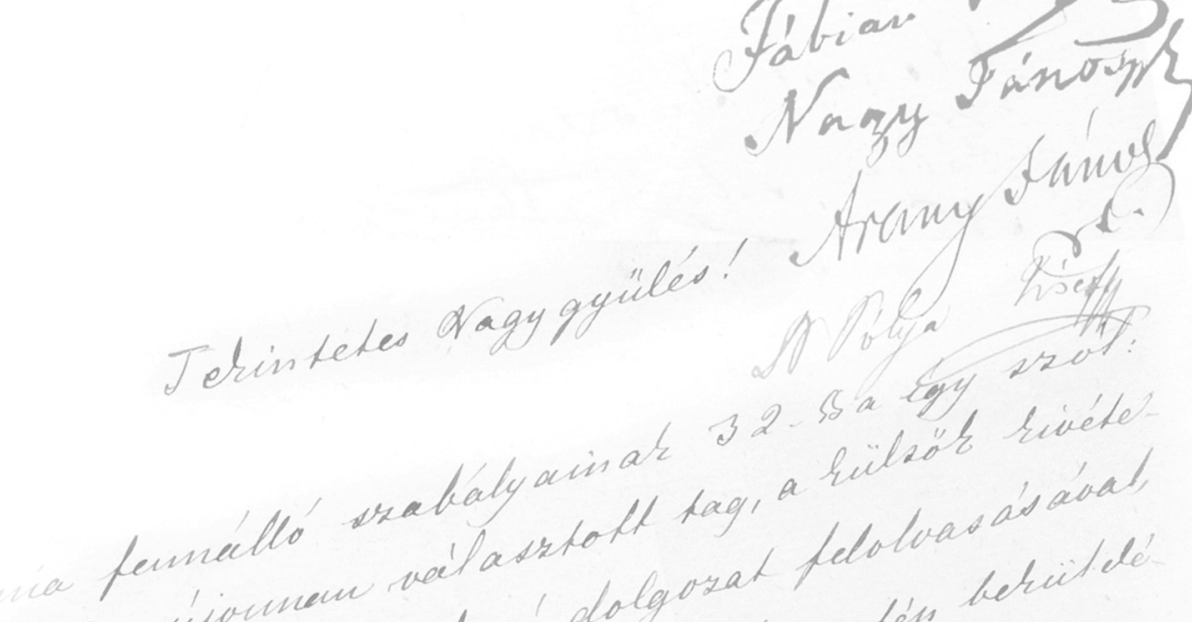

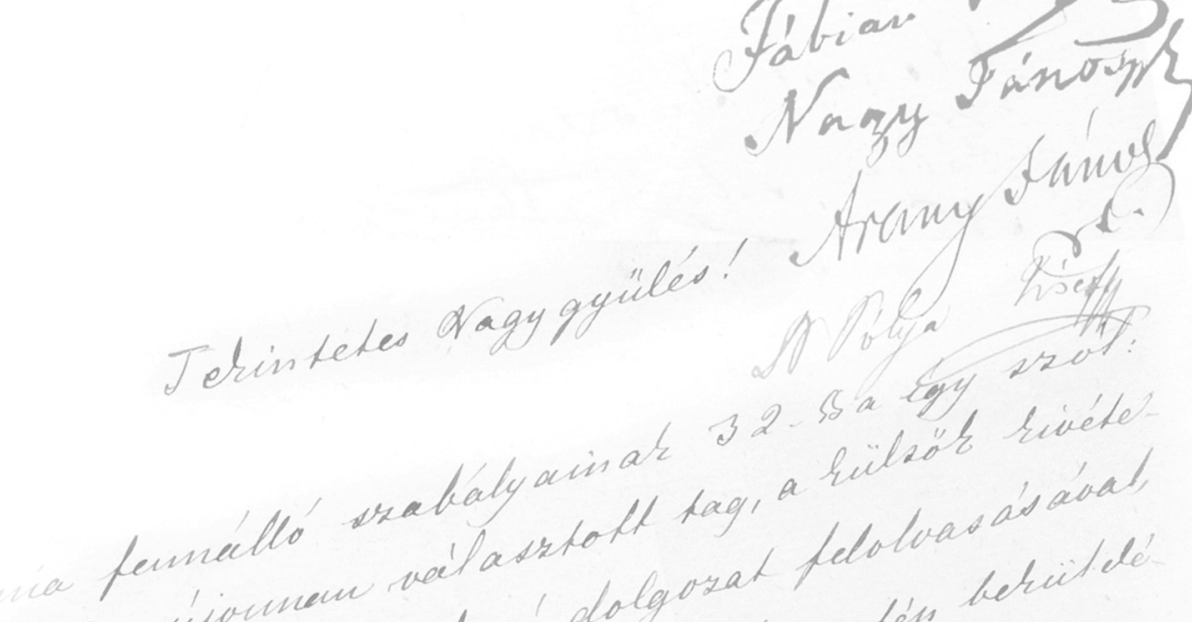

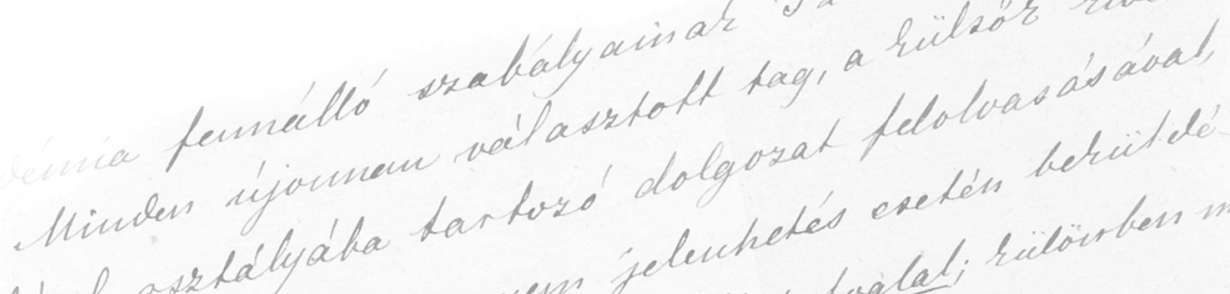

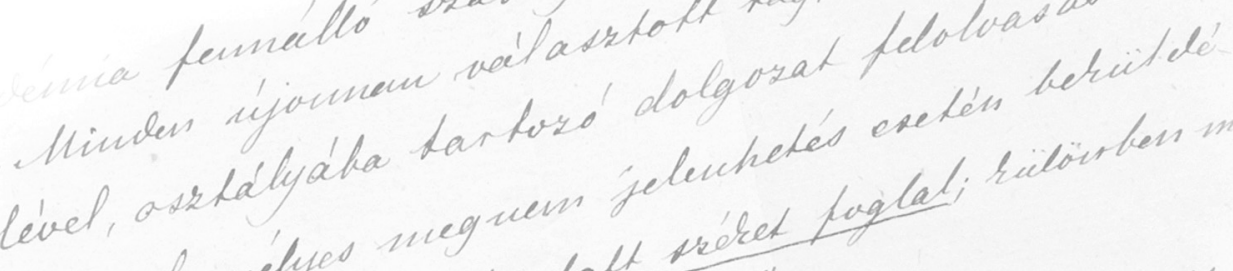
sevel, legfeleth agy misidien.

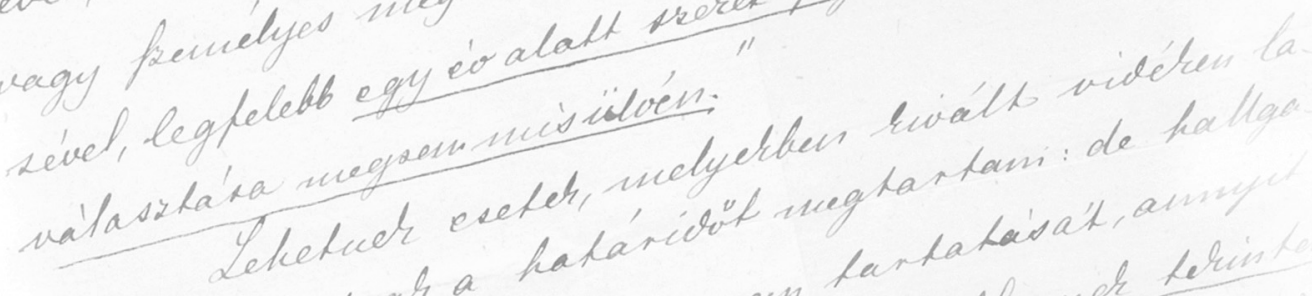

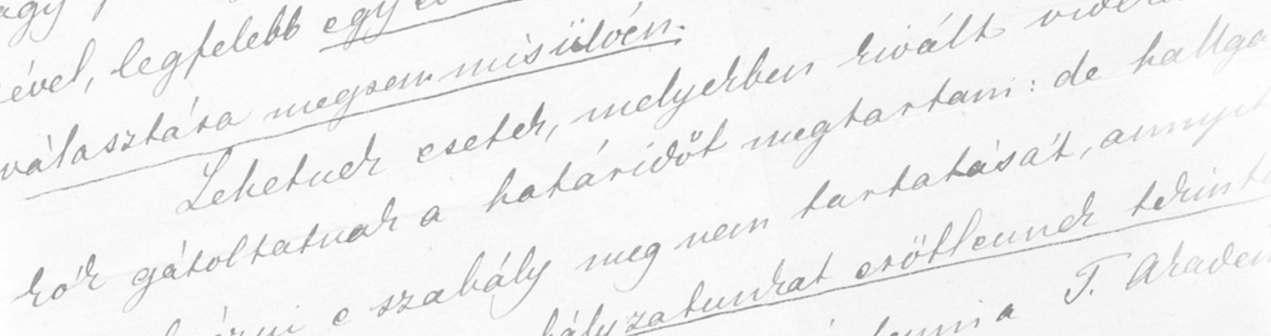

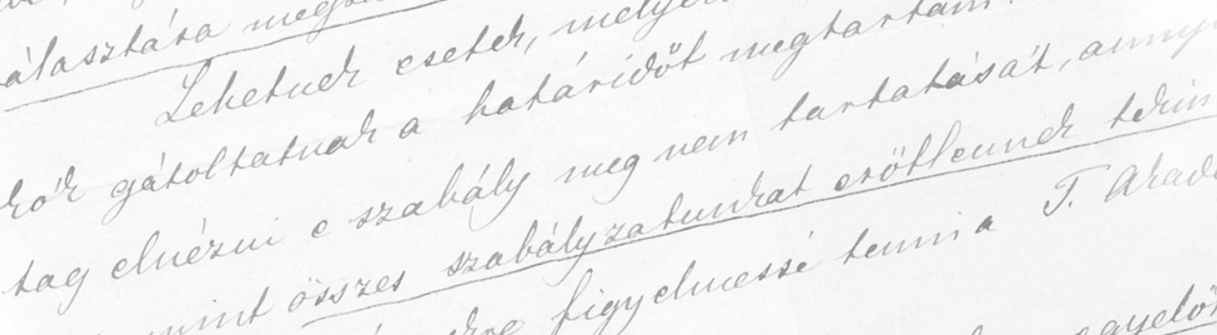

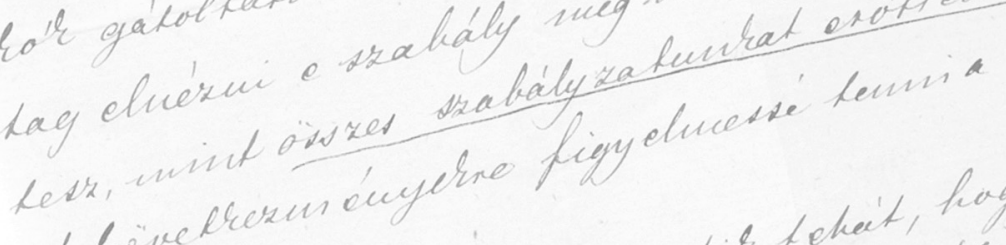

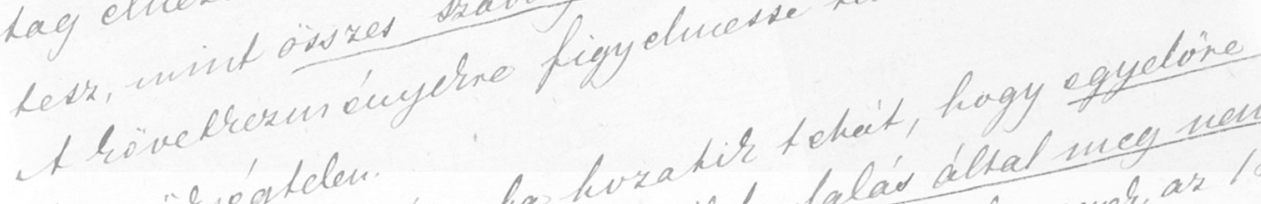
at vrierségteden.

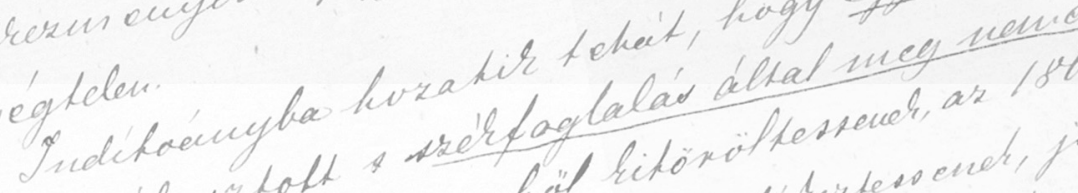

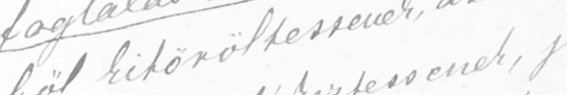




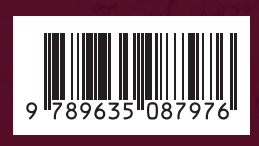

